\title{
Analisis Kapasitas Fiskal Daerah: Studi Kasus di Kabupaten Gunung Kidul
}

\author{
Jaka Sriyana \\ Universitas Islam Indonesia \\ jakasriyana@fe.uii.ac.id
}

Intergovernmental fiscal transfers are critical elements of public finance in decentralized countries. In the context of Indonesia's decentralization reforms, their design and implementation have significant impacts on the potential revenue and fiscal capacity of basic public service provision. The case of Indonesia's 2001 Big Bang decentralization illustrates the challenges associated with implementing significant reforms in the intergovernmental fiscal system. The practice of decentralization policy in Indonesia since the time has not generally improved local development performance yet. This study evaluates fiscal decentralization, focusing on fiscal capacity as the impacts of the intergovernmental fiscal equalization transfers, in the case of Gunung Kidul, Yogyakarta. The study shows a low percentage of its own revenue compared to its total budget. It indicates the failure of fiscal decentralization policy in improving local government fiscal capacity.

\section{Pendahuluan}

D embangunan nasional harus dilaksanakan secara merata di seluruh wilayah Indonesia, sehingga pembangunan daerah merupakan perwujudan dan pelaksanaannya. Pendayagunaan sumber daya alam, sumber daya manusia dan sumber daya buatan sebagai pokok-pokok kemakmuran rakyat perlu dilakukan secara terencana, terpadu dan optimal sesuai dengan pengelolaan lingkungan bagi pembangunan yang berkelanjutan.

Seiring dengan kebutuhan pembangunan yang dikeluarkan daerah, maka salah satu upaya penting yang dilakukan daerah adalah dengan pemahaman persepsi dan peningkatan kemampuan operasionalisasi.
Oleh karena itu pada setiap bidang pembangunan memerlukan pendanaan untuk membiayai setiap rincian program dan kegiatan yang telah dilaksanakan ataupun yang akan dilaksanakan sehingga rencana pembangunan nasional dan rencana pembangunan daerah pun dapat sejalan dan mempunyai benang merah yang sama (Blakely, 1994; Boadway, 1997).

Pelaksanaan otonomi daerah di Indonesia belum menunjukkan keberhasilan yang dapat menjamin terciptanya peningkatan kesejahteraan masyarakat dalam lima tahun terakhir ini. Berdasarkan UU No 32 dan No 33 tahun 2004, otonomi di Indonesia dapat dimaknai dari dua sisi, yaitu sisi politik dan sisi ekonomi. Secara politik pelaksanaan otonomi telah menunjukkan 
UNISIA, Vol. XXXII No. 72 Desember 2009

peningkatan yang signifikan dalam kewenangan daerah provinsi maupun kota/ kabupaten untuk merencanakan dan mengambil berbagai kebijakan pemerintahan. Namun dari sudut pandang ekonomi tidak menunjukkan adanya keluasan kewenangan daerah dalam merencanakan dan mengalokasikan sumber-sumber keuangan yang berasal dari daerah. Artinya masih terjadi ketergantungan keuangan (fiskal) dari pemerintah daerah kepada pemerintah pusat yang sangat besar (Murniasih, 2006).

Pada sisi lain masing-masing pemerintah kota/kabupaten menghadapi berbagai masalah mendasar yang menuntut pembiayaan. Salah satu masalah yang akan menimbulkan potensi peningkatan pembiayaan yang sangat besar adalah adanya meningkatknya kebuituhan program sebagai akibat meningkatnya dengan pesat penduduk. Kondisi ini akan menuntut pembiayaan pemerintah daerah untuk belanja pensiun, jaminan sosial, kesehatan dan fasilitas lain-lain. Selain itu dalam lima tahun mendatang kebutuhan pemerintah daerah terhadap belanja untuk penduduk usia sekolah juga masih cukup besar. Dengan demikian pemerintah kota/kabupaten dihadapkan pada masalah potensi peningkatan kebutuhan pembiayaan di tengah kondisi ketergantungan fiskal yang besar. $\mathrm{Hal}$ ini tentu menuntut adanya kebijakan transfer fiskal pemerintah pusat kepada daerah yang mampu memecahkan masalah tersebut (Brodjonegoro, Bambang, 2005).

Kajian ini merancang analisis kapasitas fiskal daerah dengan studi kasus Kabupaten Gunung Kidul, DI Yogyakarta. Analisis ini merupakan policy researh yang menggunakan pendekatan kombinasi deskriptif dan analisis kuantitatif. Dengan penelitian ini diharapkan diperoleh suatu gambaran kondisi kapasitas fiskal yang dapat meningkatkan capaian pembangunan daerah.

\section{Kajian Pustaka}

\section{Konsep Pengembangan Keuangan Daerah}

Untuk menganalisis suatu kawasan diperlukan suatu disiplin ilmu yang dikenal sebagai ilmu wilayah, yang pada hakekatnya bersifat multidisiplin ilmu yang berdimensi ruang ( region) seperti: desa, kecamatan, kabupaten, atau provinsi. Pembangunan Kawasan tidak lain adalah usaha untuk mengembangkan dan meningkatkan kesalingtergantungan dan interaksi antara sistem ekonomi ( economic system), manusia atau masyarakat ( social system), dan lingkungan hidup beserta sumber daya alam ( ecosystem) yang ada didalamnya. Kawasan adalah merupakan unit geografis dengan batas-batas tertentu yang bagianbagiannya saling tergantung satu sama lain secara fungsional ini dikembangkan dalam bentuk pembangunan ekonomi, sosial, budaya, maupun hankam secara berkeseimbangan dan berkesinambungan. Analisis Kawasan pada dasarnya bertujuan untuk menjelaskan proses bagaimana berbagai kegiatan kehidupan mengorganisasikan diri dalam suatu ruang geografi untuk mencapai tujuan bersama. Berbagai kegiatan ini meliputi kegiatan sosial budaya seperti adat-istiadat, mata pencaharian utama, dan tingkat pendidikan; kegiatan ekonomi; kegiatan pelestarian lingkungan, dan kegiatan lain yang sudah ada.

Secara garis besar, analisis pengembangan kawasan dapat dilakukan dengan memakai dua model, yaitu model Pengembangan Kawasan sisi penawaran (Supply Side Regional Development) dan model Pengembangan Kawasan sisi kebutuhan 
Analisis Kapasitas Fiskal Daerah: Studi Kasus di....; Jaka Sriyana

(Demand Side Regional Development). Analisis model pertama didasarkan pada pemikiran bahwa kembangkan dulu sumberdaya yang ada ( supplai input dan output) baru kemudian demand terhadap sumberdaya tersebut (industri hulu dan hilir) akan muncul dengan sendirinya. Sedangkan model kedua memandang perlunya disediakan lingkungan kebutuhan-kebu-tuhan konsumtif yang layak bagi masya-rakat sekarang maupun yang akan datang, yaitu dengan membangun daerah urban dan kotakota besar maupun pusat-pusat pemukiman. Kedua model ini merupakan langkah engintegrasian pusat-pusat pertum-buhan melalui perencanaan yang menye-luruh (Fitrani, Bert Hofman, dan Kai Kaiser, 2005).

Selain persiapan dan perencanaan lahan kawasan, pengembangan kawasan juga memerlukan dukungan-dukungan prasarana operasional yang harus direncanakan jauh-jauh hari sebelum pelaksanaannya. Perencanaan parasarana pendukung ini sangat menentukan kesiapan dan keberhasilan pembangunan dan pengembangan kawasan potensial di daerah untuk mempercepat pembangunan dan pertumbuhan ekonomi daerah tersebut. Diantara prasarana pendukung yang sangat penting dan akan dijelaskan berikut ini, antara lain adalah masalah kelembagaan masyarakat, teknologi yang digunakan, dan perencanaan biaya.

Investasi merupakan faktor utama yang menentukan pertumbuhan ekonomi suatu daerah/wilayah karena adanya pertumbuhan industri-industri dan kenaikan permintaan yang bersifat eksternal di luar wilayahnya sendiri. Maka pertumbuhan industri yang menggunakan sumber daya lokal dalam rangka ekspor akan menghasilkan pendapatan daerah dan penciptaan lapangan kerja. Dalam jangka panjang dapat dijelaskan berbagai faktor yang mendukung meningkatnya peluang investasi, yaitu: Sumber Daya Alam, Faktor Akumulasi Modal, Faktor Sumber Daya Manusia, Organisasi, Kemajuan Teknologi, Pembagian Kerja dan Skala Produksi, Pendidikan dan Lembaga Sosial, Kesadaran dan Kebiasaan Menabung Dan Berinvestasi, Politik dan Administratif (Bendavid, 1991; Schuvnecht, 2000).

\section{Kerangka Konseptual Potensi Pendapatan Daerah}

Dengan diberlakukannya UndangUndang No. 32 Tahun 2004 tentang Pemerintahan Daerah dan Undang-Undang No. 33 Tahun 2004 tentang Perimbangan Keuangan antara Pusat dan Pemerintahan Daerah terjadi perubahan yang prinsipil dalam melaksanakan otonomi daerah. Untuk itu daerah perlu menyesuaikan dengan paradigma baru, dimana yang dimaksud dengan otonomi daerah adalah hak, kewenangan, dan kewajiban daerah otonom untuk mengatur dan mengawasi sendiri urusan pemerintahan dan kepentingan masyarakat setempat sesuai dengan peraturan perundang-undangan (Brodjonegoro, dan Martinez-Vazquez, 2002; Sidik, 2004). Dalam Undang-Undang Nomor 32 tahun 2004 tentang Pemerintahan Daerah ditentukan sumber-sumber pendapatan daerah sebagaimana ditentukan secara implisit dalam Undang-Undang Nomor 34 Tahun 2000 tentang Pajak dan Retribusi Daerah. Menurut Undang-Undang No. 32 Tahun 2004, pasal 157 ditetapkan sumber-sumber pendapatan daerah yaitu :
a. Pendapatan asli daerah, yaitu :
1) Hasil pajak daerah
2) Hasil retribusi daerah
3) Hasil pengelolaan kekayaan dae- rah yang dipisahkan; dan
4) Lain-lain PAD yang sah;
b. Dana perimbangan, yang terdiri dari: 
UNISIA, Vol. XXXII No. 72 Desember 2009
1) Dana bagi hasil
2) Dana alokasi umum
3) Dana alokasi khusus

c. Lain-lain pendapatan daerah yang sah, yaitu penerimaan daerah yang tidak termasuk dalam jenis pajak daerah, retribusi daerah, dan hasil pengelolaan kekeyaan daerah yan dipisahkan.

Dana bagi hasil dapat dikelompokkan menjadi dua (2), yaitu dana bagi hasil yang bersumber dari pajak dan dana bagi hasil yang bersumber dari sumber daya alam. Dana bagi hasil yang bersumber dari pajak terdiri dari:

a. Pajak Bumi dan Bangunan (PBB) sektor perdesaan, perkotaan, perkebunan, pertambangan serta kehutanan.

b. Bea Perolehan Hak Atas Tanah dan Bangunan (BPHTB) sektor perdesaan, perkotaan, perkebunan, pertambangan serta kehutanan.

c. Pajak Penghasilan (PPh) Pasal 21, Pasal 25 dan Pasal 29 wajib pajak orang pribadi dalam negeri.

Dana bagi hasil yang bersumber dari sumber daya alam terdiri dari :

a. Penerimaan kehutanan yang berasal dari iuran hak pengusahaan hutan (IHPH), provisi sumber daya hutan (PSDH) dan dana reboisasi yang dihasilkan dari wilayah daerah yang bersangkutan,

a. Penerimaan pertambangan umum yang berasal dari penerimaan iuran tetap (landrent) dan penerimaan iuran eksplorasi (royalty) yang dihasilkan dari wilayah daerah yang bersangkutan,

b. Penerimaan perikanan yang diterima secara nasional yang dihasilkan dari penerimaan pungutan pengusahaan perikanan dan penerimaan pungutan hasil perikanan,

c. Penerimaan pertambangan minyak yang dihasilkan dari wilayah daerah yang bersangkutan, d. Penerimaan pertambangan gas alam yang dihasilkan dari wilayah daerah yang bersangkutan,

e. Penerimaan pertambangan panas bumi yang berasal dari penerimaan setoran bagian pemerintah, iuran tetap dan iuran produksi yang dihasilkan dari wilayah daerah yang bersangkutan.

Dana alokasi umum (DAU) untuk suatu daerah yang ditetapkan berdasarkan kriteria tertentu yang menekankan pada aspek pemerataan dan keadilan yang selaras dengan penyelenggaraan urusan pemerintahan yang formula dan perhitungan DAUnya ditetapkan sesuai Undang-Undang.

Dana alokasi khusus (DAK) dialokasikan dari APBN kepada daerah tertentu dalam rangka pendanaan pelaksanaan desentralisasi untuk :

a. mendanai kegiatan khusus yang ditentukan pemerintah atas dasar prioritas nasional,

b. mendanai kegiatan khusus yang diusulkan daerah tertentu.

Pendapatan asli daerah (PAD) merupakan sumber pendapatan daerah yang terdiri atas hasil pajak daerah, hasil retribusi daerah, hasil pengelolaan kakayaan daerah yang dipisahkan, dan lain-lain PAD yang sah. Pajak daerah merupakan sumber pendapatan yang universal yang dapat ditemui di semua negara di dunia yang menerapkan kebijakan desentralisasi. Ruang lingkup pajak ditentukan oleh pemerintah Pusat sebagaimana diatur oleh UU no.18 Tahun 1997 tentang Pajak Daerah dan Retribusi Daerah sebagaimana diubah terakhir dengan UU No.34 Tahun 2000 tentang Pajak dan Retribusi Daerah. Menurut Undang-Undang tersebut, di daerah kabupaten terdapat beberapa jenis pajak daerah, yaitu : pajak hotel, pajak restoran, pajak hiburan, pajak reklame, pajak parkir, 
Analisis Kapasitas Fiskal Daerah: Studi Kasus di....; Jaka Sriyana

pajak penerangan jalan, dan pajak pengambilan bahan galian golongan $\mathrm{C}$.

Retribusi Daerah adalah suatu pungutan yang bisa dilakukan apabila secara nyata ada pelayanan atau jasa yang diterima oleh wajib retribusi dari pemerintah daerah. Retribusi tersebut dibagi dalam 3 golongan, yaitu : retribusi jasa umum, retribusi jasa usaha, dan retribusi untuk perijinan tertentu

Perusahaan Milik Daerah merupakan usaha Daerah untuk memperoleh pendapatan guna pembiayaan penyelenggaraan urusan rumah tangga Daerah, dengan menyisihkan sebagian dari kekayaan Daerah. Disamping untuk memperoleh pendapatan perusahaan Daerah juga dimaksudkan sebagai upaya peningkatan pelayanan kepada masyarakat dalam bidang tertentu.

Sedang Lain-lain pendapatan Asli Daerah dapat berasal dari usaha daerah yang sah yang dapat diperoleh secara sah selain pendapatan sebagaimana dikategorikan seperti tersebut diatas, seperti sumbangan pihak ketiga. Sumber-sumber pendapatan tersebut dapat dikembangkan baik secara intensif maupun secara ekstensif guna meningkatkan pendapatan daerah. Pengembangan pendapatan Daerah selain Pendapatan Asli Daerah sangat tergantung kepada kemampuan Daerah dan kegiatan yang bisa dilakukan oleh daerah sendiri atau perkembangan perekonomian Daerah.

\section{Kriteria Pajak Daerah Dan Retribusi Daerah}

Pajak daerah yan dipungut oleh Pemerintah Daerah tingkat Kabupaten/Kota menurut UU No.18 Tahun 1997 tentang Pajak Daerah dan Retribusi Daerah sebagaimana telah diubah terakhir dengan UU No.34 Tahun 2000 terdiri dari pajak hotel, pajak restoran, pajak hiburan, pajak reklame, pajak penerangan jalan, pajak pengambilan bahan galian golongan $\mathrm{C}$, serta pajak parkir

\section{1) Pajak Hotel}

Pajak hotel adalah pajak atas pelayanan hotel. Hotel adalah bangunan yang khusus disediakan bagi orang untuk dapat menginap/beristirahat, memperoleh pelayanan, dan/atau fasilitas lainnya dengan dipungut bayaran, termasuk bangunan lainnya yang menyatu, dikelola dan dimiliki oleh pihak yang sama, kecuali untuk toko dan perkantoran.

\section{2) Pajak Restoran}

Pajak Restoran adalah pajak atas pelayanan restoran. Restoran adalah tempat menyantap makanan dan/atau minuman, yang disediakan dengan dipungut bayaran. Menurut Peraturan Menteri Dalam Negeri No 13 Tahun 2006 termasuk pajak restoran adalah pajak rumah makan, cafe, kantin dan katering, serta usaha jasa boga lainnya.

\section{3) Pajak Hiburan}

Pajak Hiburan adalah pajak atas penyelenggaraan hiburan. Hiburan adalah semua jenis pertunjukkan, permainan, permainan ketangkasan, dan/atau keramaian dengan nama dan bentuk apapun, yang ditonton atau dinikmati oleh setiap orang dengan dipungut bayaran, meliputi tontonan film/bioskop, pagelaran kesenian/ musik/tari/busana, kontes kecantikan, kontes binaraga, pameran, diskotik, karaoke, klub malam, sirkus/akrobat/sulap, permainan bilyar, permainan golf, permainan bowling, pacuan kudda, balap kendaraan bermotor, permainan ketangkasan, panti pijat/refleksi, mandi uap/spa, pusat kebugaran dan pertandingan olah raga (Peraturan Menteri Dalam Negeri No 13 Tahun 2006). 
UNISIA, Vol. XXXII No. 72 Desember 2009

\section{4) Pajak Reklame}

Pajak Reklame adalah pajak atas penyelengaraan reklame. Reklame adalah benda, alat, perbuatan, atau media yang menurut bentuk dan corak ragamnya untuk tujuan komersial. Dipergunakan untuk memperkenalkan, menganjurkan, atau memujikan suatu barang, jasa ataua orang, ataupun untuk menarik perhatian umum kepada suatu barang, jasa, atau orang yang ditempatkan atau yang dapat dilihat, dibaca, dan/atau didengar dari suatu tempat oleh umum, kecuali yang dilakukan oleh Pemerintah. Dalam Peraturan Menteri Dalam Negeri No 13 Tahun 2006 yang termasuk dalam pajak reklame adalah reklame papan/ billboard/videotron/megatron, reklame kain, reklame melekat/stiker, reklame selebaran, reklame berjalan, reklame udara, reklame apung, reklame suara, reklame film/slide, dan reklame peragaan.

\section{5) Pajak Penerangan Jalan}

Pajak Penerangan Jalan Raya adalah pajak atas penggunaan tenaga listrik dengan ketentuan bahwa di wilayah daerah tersebut tersedia penerangan jalan yang rekeningnya dibayar oleh Pemerintah Daerah. Penerangan jalan adalah penggunaan tenaga listrik untuk menerangi jalan umum yang rekeningnya dibayar oleh Pemerintah Daerah. Dalam hal tenaga listrik disediakan oleh PLN maka pemungutan Pajak Penerangan Jalan dilakukan oleh PLN. Ketentuan lebih lanjut mengenai pemungutan Pajak Penerangan Jalan tersebut diatur dengan Keputusan Menteri Dalam Negeri dengan pertimbangan Menteri Keuangan.

6) Pajak Pengambilan Bahan Galian Golongan C

Pajak Pengambilan Bahan Galian Golongan C adalah pajak atas kegiatan pengambilan bahan galian golongan $\mathrm{C}$ sesuai dengan peraturan perundang-undangan yang berlaku. Bahan galian golongan $\mathrm{C}$ adalah bahan galian yang terdiri dari asbes, batu tulis, batu setengah permata, batu kapur, batu abung batu permata, bentonit, dolomit, feldspar, garam batu (halite); grafit, granit/ andesit, gips, kalsit; kaolin, leusit; magnesit, mika, marmer; nitrat; opsidien; oker; pasir dan kerikil; pasir kuarsa; perlit; phospat; talk; tanah serap; tanah diatome; tanah liat; tawas; tras; yarosif; zeolit; basal; dan trakkit.

\section{7) Pajak Parkir}

Pajak parkir adalah pajak yang dikenakan atas tempat parkir yang disediakan oleh orang pribadi atau badan, baik yang disediakan berkaitan atas pokok usaha maupun yang disediakan sebagai suatu usaha, termasuk penyediaan tempat penitipan kendaraan bermotor dan garasi kendaraan bermotor yang memungut bayaran.

\section{Retribusi Daerah}

Retribusi menurut UU No.18 Tahun 1997 tentang Pajak Daerah dan Retribusi Daerah sebagaimana telah diubah terakhir dengan UU No.34 Tahun 2000 dan direvisi lagi menjadi UU No. 28 tahun 2009, dikelompokkan menjadi 3 (tiga) yaitu retribusi jasa umum, retribusi jasa usaha, dan retribusi perijinan tertentu. Untuk menetapkan kebijakan umum tentang prinsip dan sasaran dalam penetapan tarif retribusi, baik retribusi jasa umum, retribusi jasa usaha maupun retribusi perijinan tertentu, ketiganya ditetapkan dengan Peraturan Pemerintah. Besarnya retribusi yang harus dibayar oleh orang pribadi atau badan yang menggunakan jasa yang bersangkutan dihitung dari perkalian antara tingkat penggunaan jasa dan tarif retribusi. Tingkat penggunaan jasa dapat dinyatakan sebagai kuantitas penggunaan jasa sebagai 
Analisis Kapasitas Fiskal Daerah: Studi Kasus di....; Jaka Sriyana

dasar alokasi beban biaya yang dipikul daerah untuk penyelenggaraan jasa yang bersangkutan, sedangkan tarif retribusi adalah nilai rupiah atau persentase tertentu yang ditetapkan untuk menghitung besarnya retribusi yang terutang. Tarif dapat ditentukan seragam atau dapat diadakan pembedaan tentang golongan tarif sesuai dengan prinsip dan sasaran tarif tertentu.

\section{1) Retribusi Jasa Umum}

Jasa umum merupakan jasa yang disediakan atau diberikan oleh Pemerintah Daerah untuk tujuan kepentingan dan kemanfaatan masyarakat umum. Bentuk jasa umum yang disediakan atau diberikan oleh Pemerintah Daerah kepada masyarakat umum diwujudkan dalam jasa pelayanan. Dengan demikian, Retribusi Jasa Umum adalah retribusi yang dikenakan terhadap orang pribadi atau badan yang menggunakan/menikmati pelayanan jasa umum yang disediakan atau diberikan oleh Pemerintah.

\section{2) Retribusi Jasa Usaha}

Retribusi Jasa Usaha merupakan pelayanan yang disediakan oleh Pemerintah Daerah dengan menganut prinsip komersial karena pelayanan tersebut belum cukup disediakan oleh swasta. Adapun kriteria jasa pelayanan usaha yang dapat dikenai retribusi jenis ini, yaitu:

a. Jasa tersebut bersifat komersial yang seyogyanya disediakan oleh swasta, tetapi pelayanan sektor swasta dianggap belum memadai.

b. Harus terdapat harta yang dimiliki atau dikuasai oleh Pemerintah Daerah dan belum dimanfaatkan secara penuh oleh Pemerintah Daerah seperti tanah, bangunan, dan alat-alat berat.

\section{3) Retribusi Perijinan Tertentu}

Retribusi Perijinan memiliki peran ganda. Selain berfugsi utama sebagai pengatur, retribusi perijinan juga berfungsi sebagai sumber pendapatan daerah. Tepatnya, fungsi utama perijinan merupakan instrumen yang digunakan untuk melakukan pengaturan, pembinaan, pengendalian, maupun pengawasan. Hal ini dimaksudkan guna melindungi kepentingan umum dan menjaga kelestarian lingkungan. Pengaturan, pengawasan, pengendalian, dan pengarahan ini diperlukan agar masyarakat tidak sesuka hatinya melakukan kegiatan ekonomi dan kegiatan lainnya di luar ketentuan yang diberikan oleh Pemerintah Daerah yang dapat membahayakan kepentingan umum dan kelestarian lingkungan.

\section{Metode Analisis}

\section{Analisis Potensi PAD}

Analisis yang terkait dengan penghitungan potensi adalah tahap pengumpulan atau inventarisir data. Tujuannya adalah: pertama, sebagai dasar untuk pengembangan potensi pendapatan daerah yang realistis atau mendekati keadaan yang sebenarnya. Kedua, sebagai dasar penyusunan program atau rencana tindakan yang diperlukan untuk meningkatkan pendapatan daerah, baik yang diarahkan kepada subjek pajak atau retribusi maupun pengelola keuangan daerah (administrasi). Ketiga, sebagai dasar penyusunan target penerimaan pendapatan daerah yang mencerminkan potensi yang ada dan kemampuan pengelolaan pendapatan daerah. Beberapa hal penting yang perlu diperhatikan pada tahap pendaftaran dan pengumpulan data ini adalah sebagai berikut: 
UNISIA, Vol. XXXII No. 72 Desember 2009

\section{a. Jenis Data Yang Diperlukan}

Jenis data yang diperlukan untuk keperluan perhitungan potensi pendapatan daerah adalah data primer maupun data sekunder. Data tersebut meliputi subjek dan objek pajak dan retribusi, besar tarif, jumlah penduduk, tingkat inflasi, PDRB, peraturanperaturan yang berkaitan dengan pengelolaan penerimaan daerah, biaya operasional untuk memungut pajak dan retribusi.

\section{b. Tahapan Pengumpulan Data}

Tahapan pengumpulan data dapat dibagi menjadi dua tahapan, yaitu:

1) Tahap Persiapan. Pada tahap ini, semua instansi yang berwenang dalam pengelolaan keuangan daerah saling bertukar pikiran untuk:

a) Mengidentifikasi jenis unsur-unsur penerimaan daerah (pajak atau retribusi) yang memiliki potensi untuk dikembangkan lebih lanjut menurut kriteria-kriteria tertentu, misalnya:

i) Pertumbuhan dan kontribusi suatu jenis komponen penerimaan daerah (pajak atau retribusi) terhadap PAD berdasarkan realisasi anggaran. Pertumbuhan dapat dihitung dengan rumus:

Pertumbuhan Tahunan:

$$
r_{T x}=\frac{T_{X 1}-T_{X t-1}}{T_{X t-1}} \times 100 \%
$$

Pertumbuhan Berganda:

$$
r_{T x}=\left[\left(\frac{T_{X 1}}{T_{X o}}\right)^{1 / n-1}-1\right] X 100 \%
$$

Sedangkan kontribusi dapat dihitung dengan rumus:

$$
\frac{T_{x 1}}{T x}
$$

ii) Besar tarif

iii) Jumlah subjek dan objek pajak

b) Memilih jenis unsur-unsur penerimaan daerah yang memerlukan penelitian lapangan lebih lanjut untuk mendapatkan data yang paling nyata.

c) Mendesain instrumen penelitian (kuesioner) baik yang diperlukan sebagai pedoman wawancara maupun observasi.

d) Menyusun distribusi waktu yang dibutuhkan untuk pengumpulan data sesuai dengan jumlah tenaga.

e) Untuk mengevaluasi kelayakan suatu unsur penerimaan daerah yang dipungut dapat dilakukan dengan merangking syarat-syarat kelayakan unsur-unsur penerimaan daerah.

2) Tahap Penelitian Pokok. Pada tahap penelitian pokok ini, metode yang digunakan adalah wawancara atau observasi sedemikian rupa sehingga semua potensi yang ada dapat diidentifikasi.

\section{b. Sasaran}

Unsur-unsur Penerimaan Daerah yang akan dijadikan sasaran rencana peningkatan penerimaan daerah adalah sebagai berikut:

1) Pajak Daerah

Jenis-jenis pajak yang dipungut oleh pemerintah daerah meliputi jenis-jenis pajak yang belum dipungut oleh pusat. Objek pajak daerah merupakan seluruh objek pajak dikurangi dengan objek pajak yang telah digunakan atau disediakan untuk pemerintah pusat. 
2) Retribusi Daerah

Retribusi adalah pungutan sebagai imbalan atas pemakaian atau manfaat yang diperoleh secara langsung oleh seseorang atau badan atas jasa yang nyata dari pemerintah daerah. Jasa ini dapat berupa jasa pekerjaan, jasa atas usaha atau milik daerah, dan jasa lainnya, termasuk jasa ijin dalam rangka pengendalian, yang secara langsung memberi manfaat bagi pemakai dan memberikan manfaat secara umum bagi masyarakat.

Dari berbagai jenis pajak dan retribusi yang akan dijadikan sasaran (dipungut), harus dipilih beberapa yang memenuhi syarat kelayakannya: seperti syarat kecukupan, keadilan, efesiensi, kelayakan administratif, dan kecocokan untuk diterapkan. Tujuan utama dari pemilihan sasaran ini adalah agar kita tidak menarik pajak atau retribusi yang tidak mencukupi, tidak adil, tidak layak secara administratif, memperburuk efesiensi ekonomi, atau yang tidak layak untuk diterapkan.

\section{Proyeksi}

\section{a. Expert Judgement}

Kemampuan dan pengalaman ekspert merupakan kata kunci untuk keberhasilan penggunaan metode ini. Ekspert dalam kaitan ini harus memiliki data dan informasi yang cukup mengenai sistem penerimaan yang berlaku, kondisi perekonomian, dan informasi tambahan lain yang relevan dengan objek yang diestimasi. Penggunaan metode ini relatif mudah dan tidak mahal. Metode ini sangat ideal digunakan untuk mengestimasi jenis pajak yang tidak mobil dan faktorfaktor yang mempengaruhinya relatif rendah, misalnya untuk Pajak Bumi dan Bangunan (PBB). Kelemahan utama metode ini terletak pada sifatnya yang subjektif, sangat tergantung pada siapa yang melakukan estimasi tersebut.

\section{b. Analisis Regresi}

Dasar penggunaan metode ini adalah bahwa pendapatan $(\mathrm{Y})$ merupakan fungsi dari variabel lain $(X 1 . . X n)$, termasuk variabel waktu (t). Variabel X ini merupakan variabel yang secara konsep teoritik dan praktik mempengaruhi pendapatan, mislanya PDRB, penduduk, investasi, infrastruktur, dll. Secara matematik dapat ditulis: $Y=a+b 1$ $\mathrm{X} 1+\ldots+\mathrm{bnXn}+\mathrm{ct}$. Salah satu asumsi yang umum digunakan dalam metode ini, adalah bahwa tingkat pertumbuhan periode selanjutnya daktisama dengan pola pertumbuhan pada periode sebelumnya. Metode ini dapat digunakan pada seluruh jenis penerimaan.

\section{Hasil Dan Pembahasan}

\section{Profil Keuangan Daerah}

Profil keuangan daerah dalam penyusunan RPIJMD bertujuan untuk membuat taksiran dana yang tersedia untuk memenuhi kebutuhan investasi programPU/Ciptakarya di Kabupaten. Gambaran umum kondisi keuangan daerah dipergunakan untuk mengetahui:

1. Struktur anggaran pendapatan dan belanja daerah yang mencakup
a) Struktur Penerimaan Daerah
b) Struktur belanja daerah

2. Trend perkembangan penerimaan

3. Trend besaran penerimaan dana pembantuan dari pemerintah atasa

4. Profil perkembangan APBD

5. Keuangan Perusahaan Daerah

Sumber data untuk analisis kapasitas daerah adalah data yang ada pada Laporan Realisasi Anggaran 2004 - 2008. Berdasarkan dokumen laporan keuangan, posisi pendapatan, belanja dan surplus defisit 
UNISIA, Vol. XXXII No. 72 Desember 2009

empat tahun terakhir dari Kabupaten Gunung Kidul tampak dari tabel berikut.

\section{Kapasitas Keuangan Kab Gunung Kidul}

Dalam analisis kemampuan keuangan daerah memerlukan data perkembangan penerimaan dan pengeluarannya sehingga memungkinkan dilakukan proyeksi kemampuan dalam lima tahun mendatang. Dalam analisis ini dihitung perkembangan realisasi pendapatan dan belanja dan dinilai rata-rata perkembangannya. Kemampuan daerah tercermin dari indikator pertumbuhan pendapatan asli daerah yang kontinyu yaitu pendapatan pajak dan retribusi. Sedangkan penyediaan dana untuk program tercermin dari besarnya public saving. Public saving dihitung dari pendapatan dikurangi belanja wajib. Jumlah ini adalah dana yang siap digunakan untuk melaksanakan programprogram pemerintah daerah. Berikut adalah kapasitas keungan daerah.

Dari data-data pendapatan yang terdiri atas pajak, retribusi, pendapatan lain dan dana perimbangan menunjukkan bahwa selama periode 2004-2008 terjadi kenaikan yang relatif lambat. Pajak daerah dan retribusi sebagai komponen utama Pendapatan Asli Daerah (PAD) belum mampu

Tabel 1. Surplus (Defisit) Keungan daerah Kabupaten Gunung Kidul

\begin{tabular}{|l|r|r|r|r|r|}
\hline \multicolumn{1}{|c|}{ Keterangan } & \multicolumn{1}{c|}{2004} & \multicolumn{1}{c|}{2005} & \multicolumn{1}{c|}{2006} & \multicolumn{1}{c|}{2007} & \multicolumn{1}{c|}{2008} \\
\hline Pendapatan daerah & $340.447,5$ & $351.298,0$ & $527.352,2$ & $573.552,4$ & $650.655,34$ \\
\hline Belanja Daerah & $347.114,3$ & $352.114,4$ & $503.624,6$ & $680.843,6$ & $688.458,13$ \\
\hline Surplus (Defisit) & $(6.666,8)$ & $(846,4)$ & $23.727,6$ & $(7.281,2)$ & $(62.197,21)$ \\
\hline
\end{tabular}

Sumber: Laporan Realisasi APBD, 2005-2008

Tabel 2. Rincian pendapatan Kabupaten Gunung Kidul

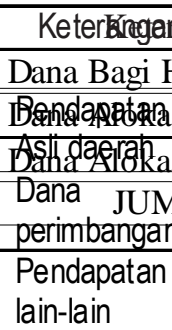

JUMLAH

Sumber: Laporan Realisasi APBD, 2005-2008

Tabel 3. Dana Perimbangan yang diterima Kabupaten Gunung Kidul

Sumber: Laporan Realisasi APBD, 2005-2008 
Analisis Kapasitas Fiskal Daerah: Studi Kasus di...; Jaka Sriyana

menunjukkan pertumbuhan yang signifikan. Kondisi ini menunjukkan semakin besarnya ketergantungan keuangan pemerintah kota Yogyakarta terhadap dana transfer dari pemerintah pusat dalam bentuk dana perimbangan, baika Dana Alokasi Umum (DAU) maupun Dana Alokasi Khusus serta dana bagi hasil lainnya. Kondisi ini tentu mengakibatkan kemampuan kabupaten untuk membiayai belanja cipta karya menjadi semkain terbatas.

\section{Proyeksi Kapasitas Fiskal}

Analisis ini dilakukan untuk memprediksi ketersediaan dana yang dapat digunakan dalam pembangunan. Beberapa masalah terkait dengan ketersediaan dana dari pemerintah kabupaten adalah:

Rendahnya kapasitas fiskal kabupaten dibanding dengan kebutuhan program yang harus dilakukan Besaran alokasi pembiayaan program dari APBD Propinsi dan

Grafik 1. Realisasi Pajak Daerah, 2004-2008

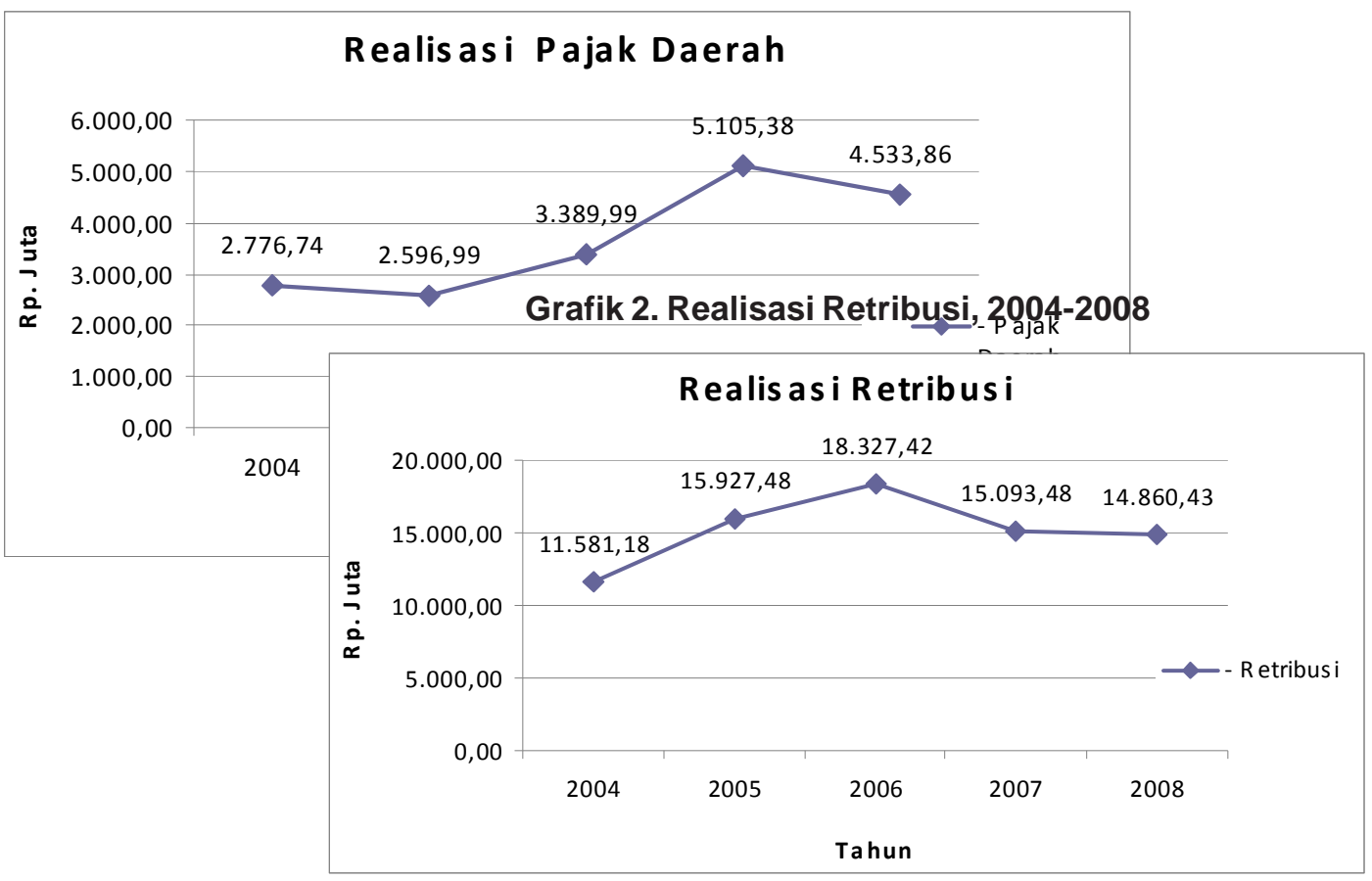


UNISIA, Vol. XXXII No. 72 Desember 2009

Grafik 3. Realisasi Pendapatan Lain, 2004-2008

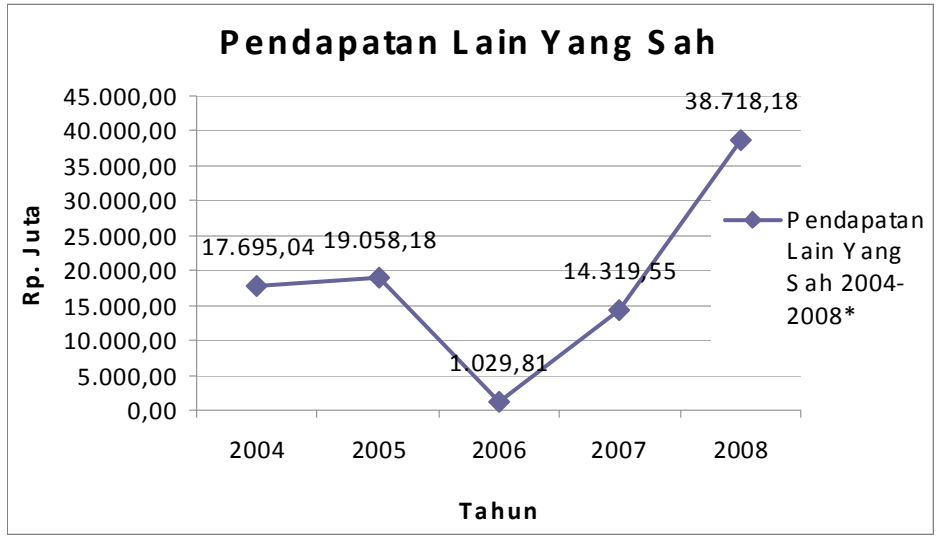

Grafik 4. Realisasi Pendapatan Asli Daerah (PAD), 2004-2008

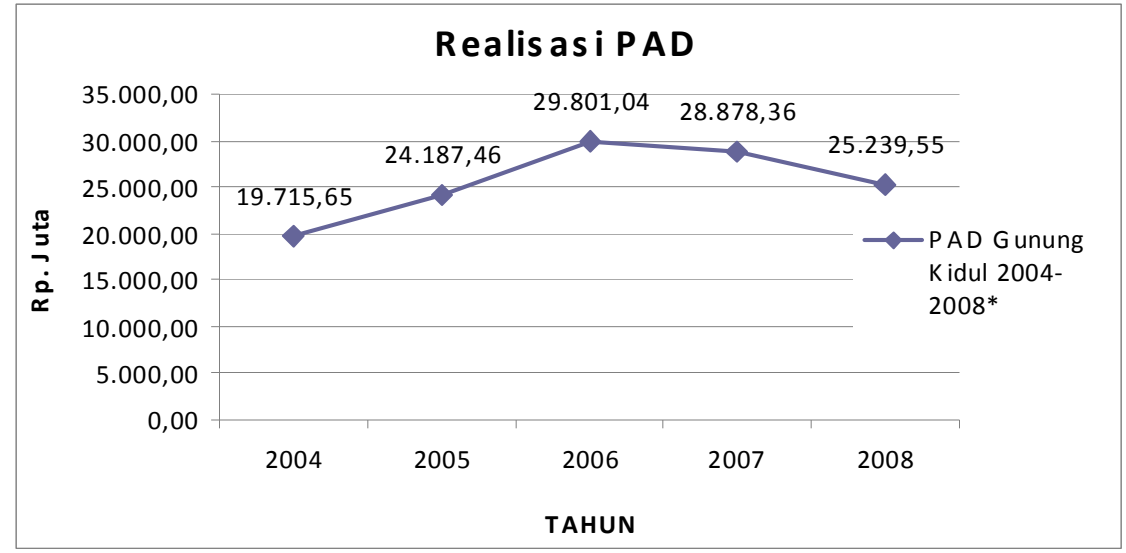

Grafik 5. Realisasi Dana Perimbangan, 2004-2008

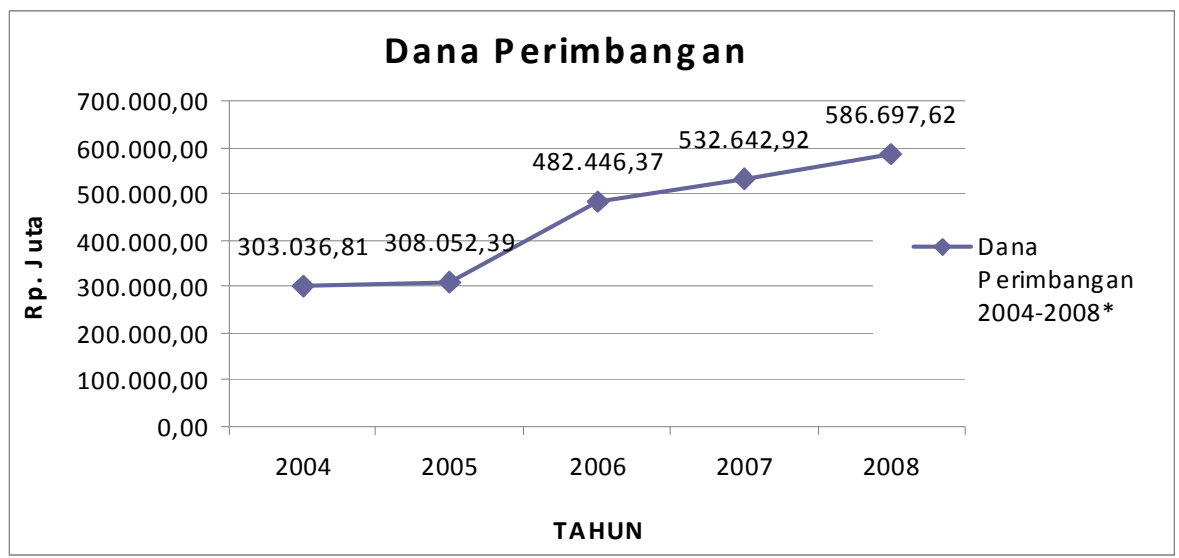


Analisis Kapasitas Fiskal Daerah: Studi Kasus di...; Jaka Sriyana

Grafik 6. Realisasi Public Saving, 2004-2008

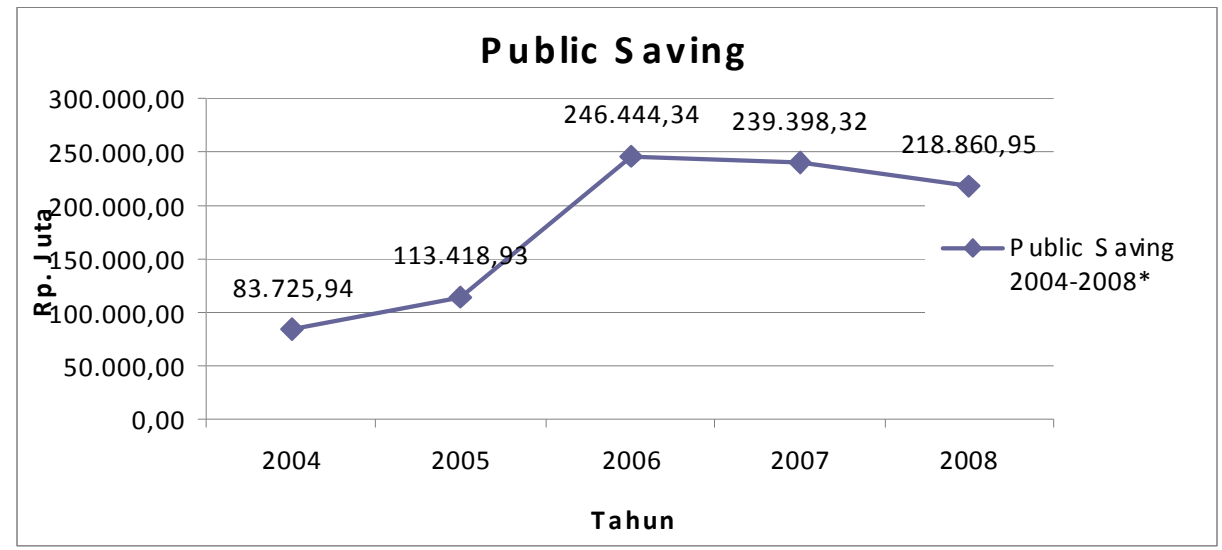

APBN untuk program pada masing-masing bidang pembangunan masih sangat. Berdasarkan program yang akan dilaksanakan menunjukkan besarnya volume program yang harus dilaksanakan untuk mengatasi masalah pada masing-masing bidang pembangunan tidak sebanding dengan kemampuan keuangan kabupaten.

Peningkatan Public Saving tidak mencukupi untuk memenuhi kebutuhan pembiayaan pembangunan. Rendahnya kapasitas fiskal daerah kabupaten untuk membiayai program dikarenakan lambatnya peningkatan penerimaan pajak dan retribusi. Begitu pula dengan dana perimbangan dari pemerintah pusat yang tidak jelas besarannya dari tahun ke tahun berikutnya Public saving menurun rata-rata 2,1\% per tahun selama 2009-2013 dengan karena kenaikan penerimaan lebih rendah daripada kenaikan belanja wajib. Kenaikan belanja wajib dikarenakan adanya peningkatan belanja pegawai yang tajam dalam 3 tahun terakhir. Tabel tentang proyeksi ketersediaan dana akan ditampilkan berikut ini.
Secara umum hasil-hasil analisis kuantitatif tentang kondisi keuangan daerah yang meliputi data-data historis penerimaan pajak, retribusi dan sumber-sumber lainnya mencerminkan kondisi keuangan daerah yang sangat rendah. Ini menunjukkan betapa tingginya ketergantungan fiskal daerah kepada pemerintah pusat dalam hal sumber keuangan. Pelaksanaan otonomi daerah tidak bisa meningkatkan sumber pendapatan secara efketif. Artinya kapasitas fiskal daerah tidak meningkat secara signifikan dalam rentang waktu pelaksanaan otonomid aerah sejak tahun1999.

Analisis proyeksi kapasitas fiskal dnegan pendekatan moderat juga tidak menunjukkan hasil adanya lonjakan potensi penerimaan daerah, yang menunjukkan ada peningkatan kapasitas fiskal. Peningkatan kapasitas fiskal daerah hanya akan terjadi jika kebijakan kewenangan pengelolaan lebih besar tentang sumber keuangan diberikan kepada daerah. Kebijakan yang bias dilakukan adalah dalam bentuk perubahan UU tentang pajak daerah dan 
UNISIA, Vol. XXXII No. 72 Desember 2009

Grafik 7. Proyeksi Pajak Daerah, 2009-2013

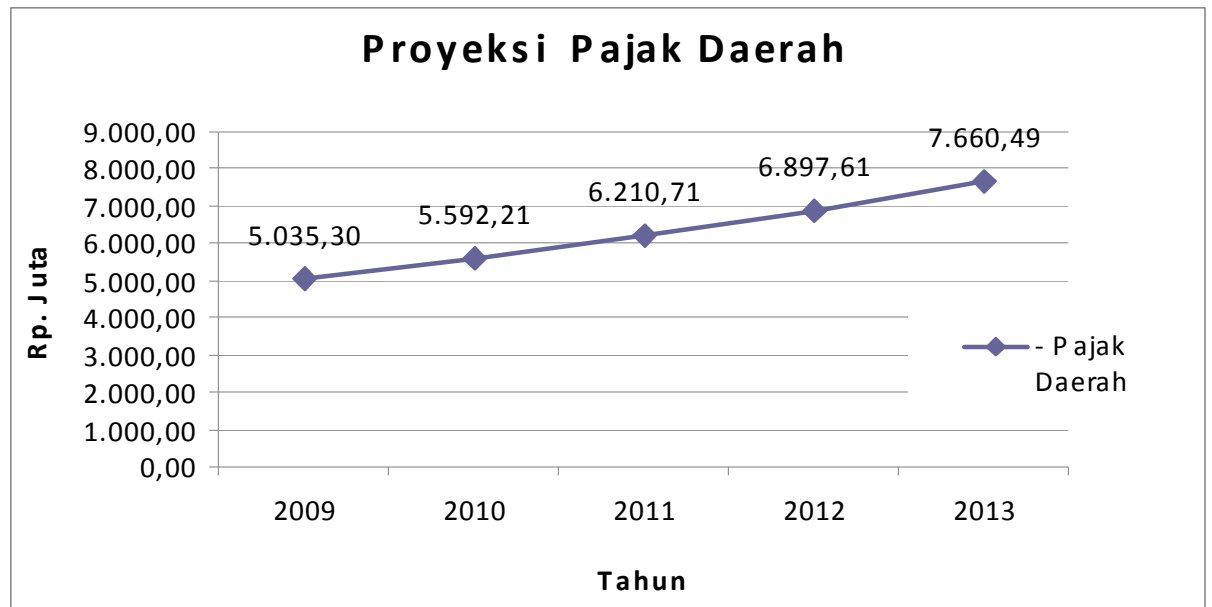

Grafik 8. Proyeksi Retribusi, 2009-2013

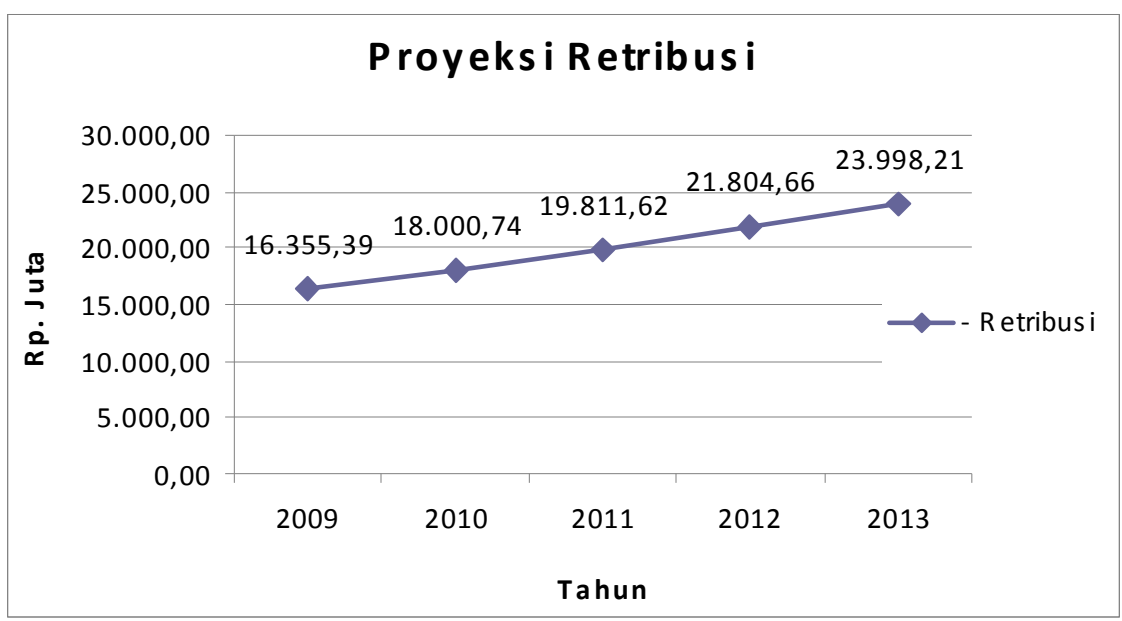


Analisis Kapasitas Fiskal Daerah: Studi Kasus di....; Jaka Sriyana

Grafik 9. Proyeksi PAD, 2009-2013

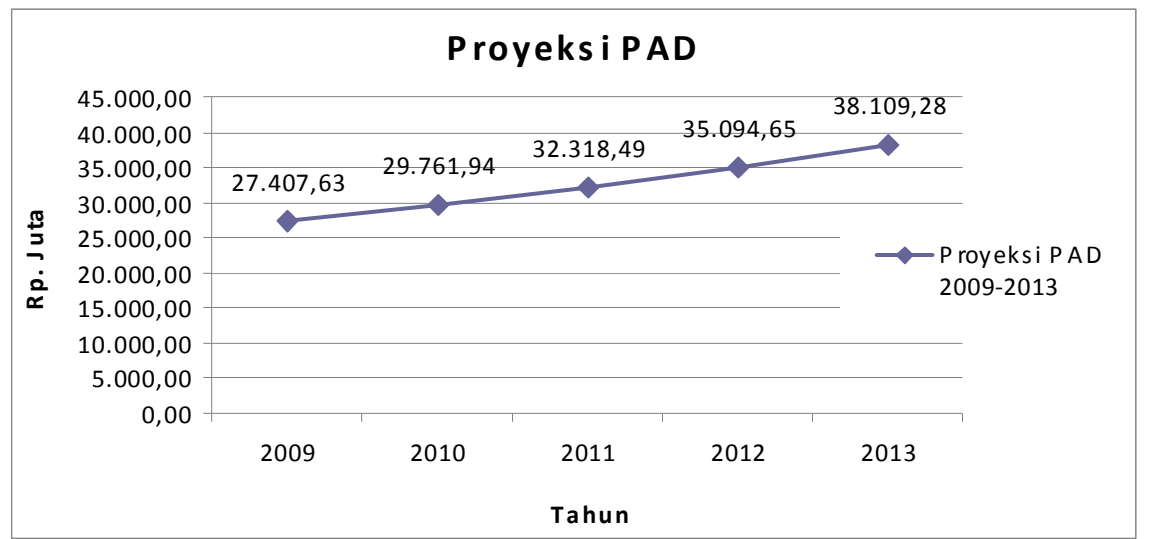

Grafik 10. Proyeksi Dana Perimbangan, 2009-2013

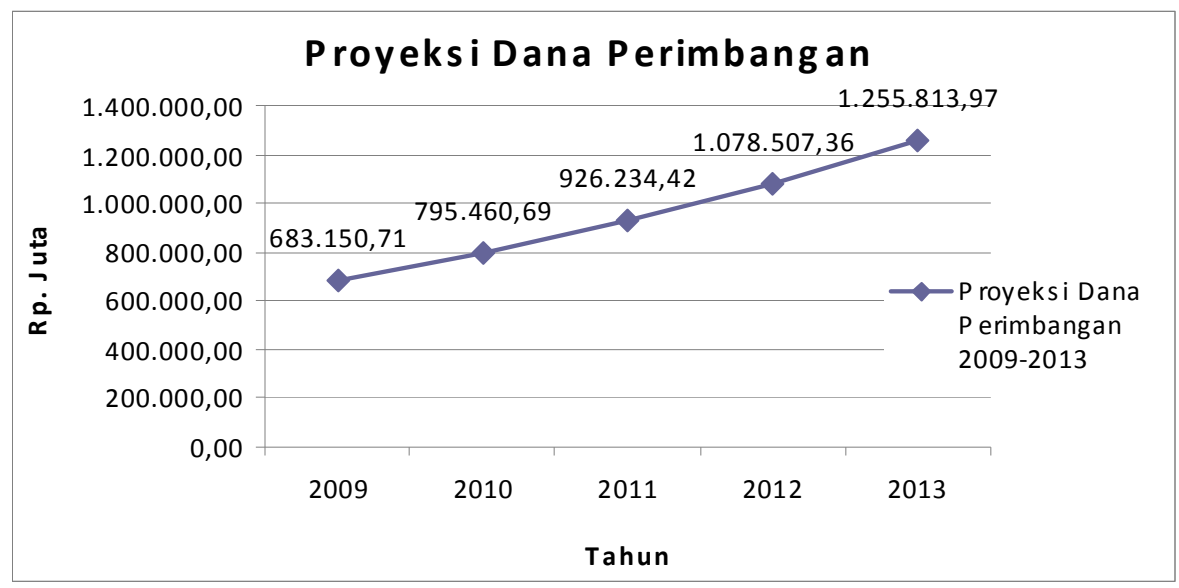


UNISIA, Vol. XXXII No. 72 Desember 2009

Grafik 11. Proyeksi Public Saving, 2009-2013

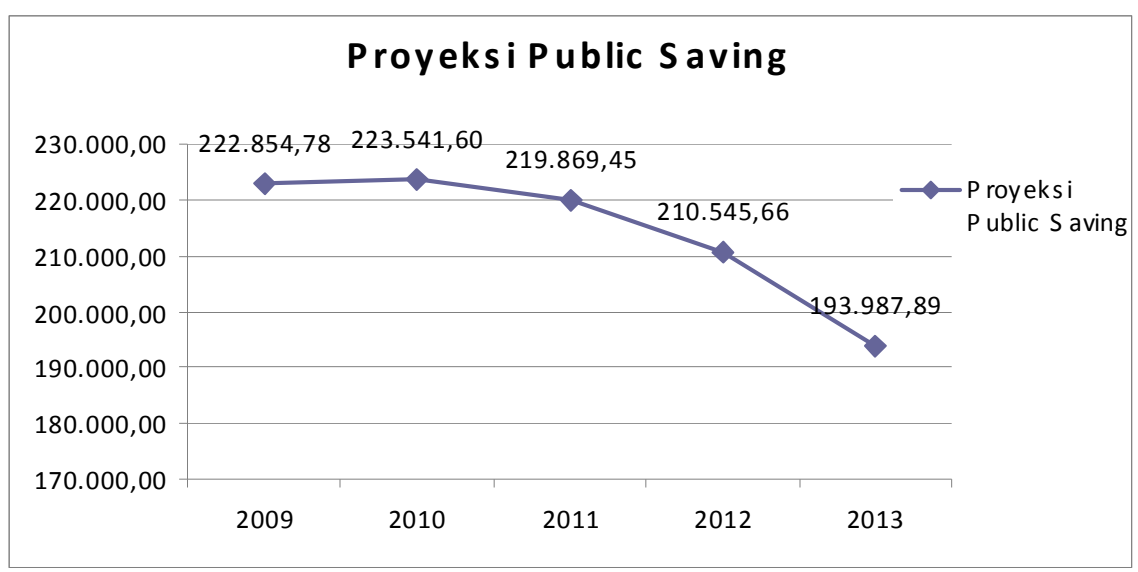

Grafik 12. Proyeksi DSCR, 2009-2013

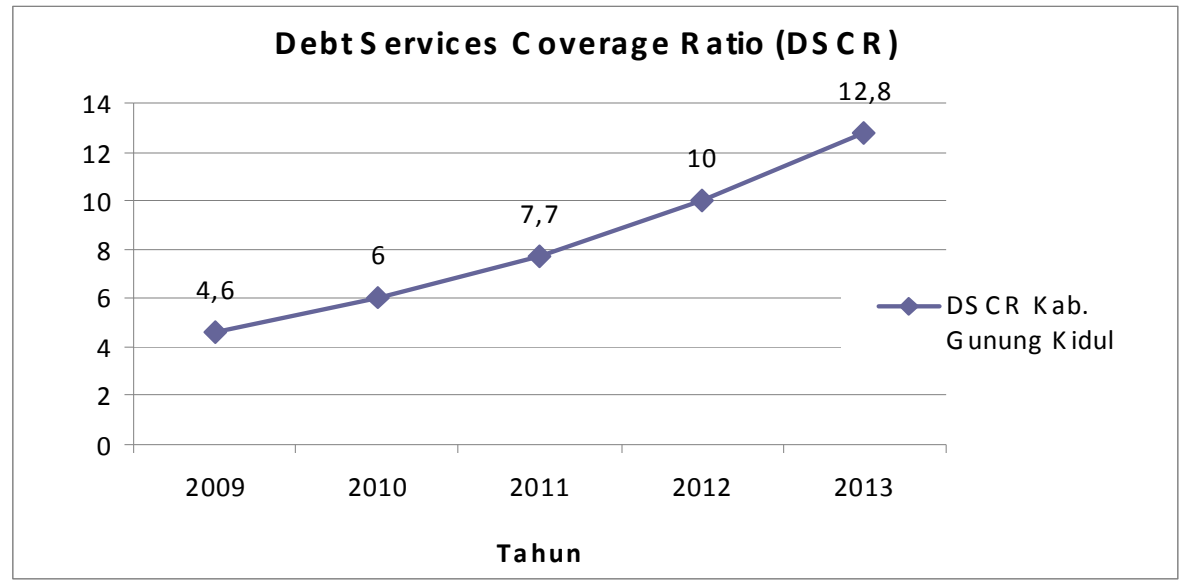

retribusi daerah yang memberikan kewenangan lebih besar kepada daerah dalam hal penentuan peraturan daerah maupun porsi bagi hasil penerimaan dari sumbersumber di daerah.

\section{Penutup}

\section{Kesimpulan}

1) Dengan diberlakukannya otonomi daerah yang luas, nyata dan bertang- gung jawab, kewenangan daerah kabupaten menjadi sangat luas, dan untuk menyelenggarakan kewenangannya itu diperlukan pembiayaan yang makin besar. Di lain pihak sumber keuangan daerah dalam hal ini Kabupaten Wonogiri yang berasal dari Pendapatan Asli Daerah masih terbatas dan tingkat ketergantungan keuangan daerah terhadap bantuan Pemerintah Pusat masih cukup tinggi 
Analisis Kapasitas Fiskal Daerah: Studi Kasus di....; Jaka Sriyana

2) Pendapatan Asli Daerah (PAD) memberikan kontribusi yang relatif kecil dalam mendukung penerimaan daerah, sedangkan proporsi terbesar berasal dari dana perimbangan dari pemerintah pusat. Ini menunjukkan bahwa kapsitas fiskal di Kabupaten Gunungkidul masih sangat rendah. Pendapatan Asli Daerah (PAD) Kabupaten Gunungkidul bersumber dari Pajak Daerah, Retribusi Daerah, Laba Perusahaan Daerah, dan Kekayaan Daerah yang dipisahkan serta lain-lain Pendapatan Asli daerah yang sah.

3) Pajak daerah bersumber dari 7 (tujuh) objek yaitu pajak hotel, pajak restoran, pajak hiburan, pajak reklame, pajak penerangan jalan, pajak pengambilan dan pengolahan tambang golongan $C$ dan pajak parkir, pajak parkir kendaraan bermotor, dan pajak pemanfaatan air bawah tanah dan air permukaan tanah.

4) Kontribusi proporsi rata-rata Laba Perusahaan daerah dan Pengelolaan Kekayaan daerah yang dipisahkan terhadap total pendapatan asli daerah masih rendah. Sumber penerimaan dari Laba Perusahaan daerah dan PengeIolaan Kekayaan daerah yang dipisahkan selama lima tahun terakhir mengalami peningkatan nominal yang berart.

5) Jenis pajak daerah yang dapat dikategorikan sebagai pajak unggulan daerah adalah pajak reklame, pajak hiburan, dan Pajak Pengambilan dan pengolahan bahan galian golongan $\mathrm{C}$.

6) Jenis retribusi yang termasuk dalam retribusi unggulan adalah retribusi pelayanan pasar, retribusi jasa usaha terminal, retribusi ijin mendirikan bangunan, retribusi ijin gangguan $(\mathrm{HO})$, retribusi ijin trayek, dan retribusi ijin hasil hutan.

\section{Rekomendasi}

1) Untuk meningkatkan kapasitas fiskal daerah perlu dilakukan perubahan sistem dan prosedur perpajakan dan retribusi terus diupayakan penyempurnaannya dengan berpedoman pada misi yang terkandung dalam UU No. 18 Tahun 1997 tentang Pajak da Retribusi dan perubahannya yaitu UU No.28 tahun 2009, dengan tetap memperhatikan asa keadilan, pemerataan bermanfaat dan kemampuan masyarakat melalui peningkatan mutu pelayanan dan kualitas aparat yang tercermin dalam peningkatan disiplin kerja, kejujuran, tanggung jawab dan dedikasi serta melalui penyempurnaan sistem administrasi. Selama ini berbagai peraturan tentang pajak dan retribusi daerah hanya menguntungkan kota dan kabupaten yang memiliki sumber daya alam melimpah.

2) Setiap akan memberlakukan peraturan daerah yang baru perlu diberlakukan sosialisasi peraturan yakni mengenai segala macam pungutan dalam jangka waktu yang cukup agar tidak menimbulkan hal-hal yang tidak diinginkan, sehingga peningkatn kapasitas fiskal lebih efektif.

3) Pendapatan daerah masih dapat ditingkatkan dengan melalui intensifikasi berupa penyesuaian tarif dan sistem penarikannya, sebagaim-ana ditentukan peraturan daerah maupun dengan ekstensifikasi dengan memperluas sumber pendapatan, baik dari pajak, retribusi, laba badan usaha daerah maupun penerimaan lain-lain.

4) Untuk memperoleh gambaran secara lebih jelas mengenai potensi penerimaan yang berasal dari perusahaan daerah, perlu dilakukan pengkajian 
UNISIA, Vol. XXXII No. 72 Desember 2009

terhadap perusahaan daerah untuk meningkatkan kapaitas penerimaan dari perusahaan secara optimal ke Kas Daerah.

\section{Daftar Pustaka}

Baghestoni dan McNown, 1994, Do Revenues or Expenditures Respond to Budgetary Disequilibria?, Southern Economic Journal, 61:311-322.

Bahl, Roy and Bayar Tumennasan. 2004. "How Should Revenues from Natural Resources be Shared in Indonesia?" in Reforming Intergovernmental Fiscal Relations and the Rebuilding of Indonesia: The 'Big Bang' Program and its Economic Consequences. Cheltenham, UK \& Northhampton, MA, USA: Edward Elgar, pp. 199-233.

Bendavid, Avrom, 1991, Regional and Economy Analysis for Practitioner, Praeger Publisher, One Madison Avenue New York.

Bird, Richard M. and Micheal Smart. 2002. "Intergovernmental Fiscal Transfers: Some Lessons from International Experience." World Development, 30:6, pp. 899-912. Deaton, Angus. 1997. The Analysis of Household Suveys: A Microeconometric Approach to Development Policy. Washington: World Bank.

Blakely, Edward J, 1994. Planning Local Economic Development Theory and Practice, $2^{\text {th }}$ edition Sage Publication Inc California

Boadway, Robin, 1997, Preparing The Public Sector for 2020: Lessons from Industrialised Countries, in Indone- sia's Public Sector in The Twenty First Century: Planning For 2020 and Beyond, Workshop Proceedings, Univeriti Kebangsan Indonesia

Brodjonegoro, Bambang (2005) The Indonesian Decentralization After Law Revision: Toward a Better Future ?". Available online at http://www.econ.hit u.ac.jp/ kokyo/APPsympo04/PDFpapers-nov/Indonesianpaper.pdf

Brodjonegoro, Bambang and MartinezVazquez (2002) An Analysis of Indonesia's Transfer System: Recent Performance and Future Prospects. Working Paper 02-13, International Studies Program, Andrew Young School of Public Policy Studies, Georgia State University. Available online at http://isp-aysps.gsu.edu/ papers/is pw p0213.pdf aysps.gsu.edu/papers/ ispwp0213.pdf

Fitrani, Fitria, Bert Hofman, and Kai Kaiser. 2005. "Unity in Diversity? The Creation of New Regions in a Decentralizing Indonesia." Bulletin of Indonesia Economic Studies, 41:1, pp. 5779.

Murniasih, Erny (2006) New Intergovernmental Equalisation Grant in Indonesia: A Panacea or A Plague for Achieving Horizontal Balance Across Regions. University of Birmingham, International Development Department.

OECD Outlook, 2002, "Fiscal sustainability: the contribution of fiscal rules," in: OECD Economic Outlook 72, pp. 117-136, Paris: Organization for Economic Cooperation and Development. 
Analisis Kapasitas Fiskal Daerah: Studi Kasus di...; Jaka Sriyana

Purchase, Bryne, 2000, The Public Sector and The Market: An International Perspective on Government and Competitiveness, in Malaysia's Public Sector in The Twenty First Century: Planning For 2020 and Beyond, Workshop Proceedings, UKM.

Schuvnecht, Ludger, 2000, Fiscal Policy Cycles and Public Expenditure in Developing Countries, Public Choice, 102: 115-130.

Sidik, Mahfud (2004) "Indonesia's Imbalance Decentralization and Its Future Direction for a Greater Taxing Power to SubNational Governments" in Heru
Subiyantoro and Singgih Riphat (eds). Kebijakan Fiskal: Pemikiran, Konsep, dan Implementasi (Fiscal Policy: Opinion, Concept, and Implementation). Jakarta: Penerbit Buku Kompas

UU No. 32/2004. Tentang Pemerintah Daerah, diakses dari: http:// www.indonesia.go.id/produk uu/ produk2004/uu2004/uu32'04.htm

UU No. 33/2004 on Hubungan Keuangan Pusat dan Daerah, diakses dari: http://www.indonesia.go.id/ produk uu/produk2004/uu2004/ uu33'04.htm 